\title{
GCU
}

Glasgow Caledonian

University

University for the Common Good

\section{Redefining welfare in Scotland - with or without women?}

O'Hagan, Angela

Published in:

Critical Social Policy

DOI:

$10.1177 / 0261018316643794$

Publication date:

2016

Document Version

Author accepted manuscript

Link to publication in ResearchOnline

Citation for published version (Harvard):

O'Hagan, A 2016, 'Redefining welfare in Scotland - with or without women?', Critical Social Policy, vol. 36, no. 4, pp. 649-671. https://doi.org/10.1177/0261018316643794

\section{General rights}

Copyright and moral rights for the publications made accessible in the public portal are retained by the authors and/or other copyright owners and it is a condition of accessing publications that users recognise and abide by the legal requirements associated with these rights.

Take down policy

If you believe that this document breaches copyright please view our takedown policy at https://edshare.gcu.ac.uk/id/eprint/5179 for details of how to contact us. 


\title{
Redefining welfare in Scotland - with or without women?
}

\section{ANGELA O'HAGAN \\ Glasgow Caledonian University, Scotland}

\begin{abstract}
The combination of the impact of welfare reform by the UK government and the opportunity for change presented by the debate on Scottish independence produced a profusion of alternative proposals for social security from scholars, formal political parties, the Scottish Government, and a range of think tanks and civil society organisations. The extent to which these proposals demonstrated considered gender analysis or specific objectives to address economic and social constraints principally experienced by women and arising from the constraints of gender relations varied considerably. This paper considers the extent to which concerns for alternative approaches to social security policy reflect a political commitment to women's economic and social wellbeing in a future Scotland through an analysis of proposals from key policy documents prior to the Referendum and the proposals emerging in the post-Referendum period.
\end{abstract}

Keywords: devolution, equality, wellbeing, social policy

\section{Introduction}

Visions of what a 'new Scotland' might look like as an independent country or as a re-formed member of the United Kingdom crowded the minds and television screens of many in Scotland in 2014. Just as the first phase of devolution had generated expectations for innovative and progressive social policy (Mooney et al, 2006), aspirations were high during the independence debate. But was the possibility of a more gender equal Scotland at the forefront of these discussions? What proposals for the social security of the citizens of a future Scotland were forthcoming from the political parties and the plethora of civil society organisations engaged in the independence debate and specifically for the social protection, wellbeing, and independence of the women in Scotland? Was the economic, political and social status of women a central political concern beyond the organised feminist movement?

Following a brief overview of the enduring inequality experienced by women, the main body of the article is a critical feminist analysis of how social security policy has been developing in Scotland and the extent to which policy proposals from political parties and other engaged organisations demonstrated an understanding and analysis of gender inequality.

The opportunity of political change presented by the independence referendum and the surrounding debate opened up political and policy space to explore and bring forward alternative approaches to social security for a future Scotland and as a response to the 'welfare reform' actions of the UK government. Using evidence from a range of sources produced during and since the Scottish independence referendum in 2014 this article draws on concepts from feminist critical 
frame analysis (Lombardo, Meier, and Verloo, 2009) in discussing considers the extent to which there was any 'grand vision for gender equality' as aspired to by Helga Maria Hernes' conceptualisation of 'the women-friendly welfare state' (1987). It also discusses the agency of women as political actors and the possibilities within the political opportunities presented by the independence debate and subsequent developments to advance women's equality and recast gender relations.

The evidence of gender analysis, or the absence of such, is taken from substantive policy proposals of the main formal political parties - Scottish Labour, Scottish Conservative and Unionists, Scottish Green Party, Scottish National Party (SNP), Scottish Liberal Democrats, and analyses produced by civil society organisations. Across these policy networks, the debate has been framed around 'welfare' and welfare 'reform'. Feminist organisations including the UK and Scottish Women's Budget Groups have consistently challenged this dominant frame from the UK government and other parties of the right, arguing against the damaging impact on women of spending decisions and for a shift in government discourse to social security and social protection as proposed in Plan F produced by the UK and Scottish Women's Budget Groups (2015).

\section{Gender Equality in Scotland}

Ongoing reforms to welfare and tax by the UK government, cuts in public spending and the withdrawal of public services in the UK and Scotland are being implemented against a backdrop of ongoing constitutional change and pre-existing gendered inequalities. Evidence to the Scottish Parliament Welfare Reform Committee Inquiry on Women and Welfare in 2015 highlighted a number of these core issues.

- Twice the amount of women's income is derived from the tax credits and benefits system than men's

- $59 \%$ of carers are women, and $84 \%$ of those caring for children and other family members are women

- Women are more likely to work part-time which, along with the persistent gender pay gap, results in lower incomes and earnings for women relative to men

- $92 \%$ of single parent households are headed by women

- $43 \%$ of children in single parent households are poor, almost double the percentage (22\%) in couple households

- Women experiencing domestic abuse are additionally vulnerable as they may lack access to income because of power imbalances within households, reinforcing the need for independent access to social security support to enable them to leave an abusive situation (Scottish Parliament, 2015a). 
In 2002, Jane Lewis warned that women were "being asked to bear the main burden of welfare state restructuring" (2002:333). Five years of reductions in public spending imposed by the UK government have seen Lewis' prediction unfold with even greater severity. According to the UK Women’s Budget Group (UKWBG), by 2014 85\% (£22billion) of the £26billion cuts had directly affected women's income and following the 2015 UK Government Autumn Statement, 75\% of the $£ 16$ bn net cumulative revenue in spending cuts and tax rises announced since the 2015 election had been borne by women resulting in $81 \%$ overall of the consolidation in personal tax rises and cuts to social security spending between 2010-2020 (UKWBG, 2014, 2015).

These political choices have cut spending and increased taxation in a ratio of 82:18\% (Institute for Fiscal Studies, 2015:1). They have particularly affected women experiencing poverty, especially older women, lone parents, and disabled women, who have variously been pushed into poverty, out of the labour market, and back into increased caring roles to compensate for the withdrawal of public services. Women are facing what The Fawcett Society (Fawcett, 2013) has called the 'triple jeopardy' of job cuts, spending cuts and service cuts. Alternative social security provisions therefore, must be considered within the context of the existing disparities [that] arise from the wider political, economic and social context within which women are situated (Graham and McQuaid, 2014).

The Scottish National Party (SNP), who have formed the Scottish Government since 2007 claims to have focused its efforts on what its ministers have described as 'mitigating the worst excesses of the Westminster government' (The Guardian, 2011; see also Scottish Government, 2013, 2015a). Successive Scottish Government Budgets have introduced anti-austerity measures such as the Scottish Welfare Fund, providing crisis grants and loan funding to individuals and households; and Discretionary Housing Benefit to compensate social housing tenants affected by the UK Government's 'spare room subsidy' known as the "Bedroom Tax". Rummery (2015:1) considers these measures to be evidence of the Scottish Government offering a "credible alternative to 'austerity-driven welfare"' Others, however, have argued that these measures have been insufficient, especially in relation to women experiencing poverty as a result of the triple jeopardy (SWBG, 2013; Engender, 2014).

Gender equality advocates have been persistent and influential since devolution, particularly in the areas of gender budgeting, gender equality and economic policy, and gender based violence and women's political representation (Mackay, 2010). These include the Scottish Women's Budget Group (SWBG) which has been a member of the Scottish Government's Equality and Budgets Advisory Group (EBAG) since 2001 and an influential voice through the Scottish Parliament committees (O'Hagan, 2015). Engender, a national feminist campaigning organisation has led the debate on women and 'welfare' throughout the independence referendum and since. 
As to the extent to which there has been a strong public demand for more progressive social security policy, there is evidence from polling data and other commentary that questions perceptions of Scotland as politically and popularly more committed to social justice than elsewhere in the UK (see Curtice, 2014; Rummery, 2015). The rhetoric is strong and social justice and equality are dominant policy frames as evidenced in the recent review of Scotland's Economic Strategy. While the "overarching purpose of government" remains "to create a more successful country, with opportunities for all of Scotland to flourish, through increasing sustainable economic growth" (Scottish Government, 2015b:1), the economic strategy is now built upon the two key pillars of increasing competitiveness and tackling inequality. The focus on tackling inequality is framed as an economic and social justice imperative: inequality is described as a drag on growth and impediment to individual wellbeing.

\section{Political change as an opportunity for feminist policy change}

The potential of promoting feminist policy change by capitalising upon windows of political opportunity, such as constitutional change, are well established in the literature (Banaszack et al. 2003; Beckwith, 2007; Vickers, 2013) and in territorial politics (Keating and Wilson, 2009), where the creation of political opportunity structures potentially open up the policy space for new actors and arenas.

Women's political organising in Scotland both before and since devolution has been a dynamic processes, aiming to increase women's presence inside political institutions and outside the institutions as effective advocates for gender equality (Charles and Mackay, 2013). Throughout the referendum debate and since, women's organisations consulted, deliberated and promoted alternative analysis and proposals to address and improve the positive of women and to present the possibility of a more gender equal Scotland (O'Hagan, 2014a).

Annesley's (2007) historical examples from elsewhere of the impact of women's organised campaigning on welfare reform, maximised through opportunities for social change are helpful in analysing the experience in Scotland. Annesley (2007: 455) confirms that the effectiveness of women's political agency is not "automatic" but rather depends on the combination of open windows of opportunity and women "as political agents...shap[ing] the terms of reference or discourse of the reform process and hav[ing] the institutional capacity to get their demands heard and implemented".

Clearly the extended debate leading up to the referendum on Scottish independence was such a window of opportunity. Over two years before the vote on 18 September 2014 policy proposals were generated in political parties, by feminist and women's organisations, in anti-poverty organisations and alliances, and by newly established 'think tanks', policy websites and blogs. 
Civic and political Scotland responded enthusiastically to the opportunity to envision a different country, or at least advance alternative approaches to social and economic wellbeing within the Union, amplifying the expectations of first round devolution which had opened up a "reinvigorated" scope of policy domains (Mooney et al, 2006:485).

In 2014, women trade unionists, political activists, and public intellectuals were visible even in the largely male-dominated world of political campaigning and blogging. Among the principal initiatives within the broad 'Yes' campaign were Women for Independence (established in 2012 and claiming 10,000 members by 2015); the Radical Independence Campaign; the blogger website Bella Caledonia, and individual political bloggers such as Kate Higgins (@burdseyeview), and Lesley Riddoch, author, journalist and campaigner who advocates Nordic-style taxation in support of Scandinavian style welfare state, local governance and childcare/social care regimes (Riddoch, 2013, 2015).

Women as voters were keenly targeted by the political parties and campaigning organisations on both sides of the question focusing on key pressure points of significance to women especially social security, pensions, social and health care (Ormiston, 2014). The wider questions of the status of the currency, economy, taxation, environment, transport, defence and international relations/foreign policy, and EU membership in an independent Scotland were all in play.

'Social justice' became a key political battleground on both sides of the referendum question (O'Hagan, 2016). For the wider 'Yes' campaign it was a platform for policy proposals on poverty and inequality (including welfare), participation and inclusion, equality and human rights. The "Better Together" campaign for a 'no' vote crafted its claims of the progressive potential of remaining in the Union as a call for social justice. The Labour Party focused on the need to maintain solidarity with people in England and Wales, especially those worst affected by reductions in public spending and changes to the UK welfare and taxation regimes (Scottish Labour, 2014a).

Since the financial crisis and recessions of the late-2000's there has been a resurgence of the neoconservative entrenchment evident in the 1980's (Mishra, 1990). Increasingly the justification of 'welfare reform' at the UK level has been a characterisation of 'welfare' as a scourge and the need for policy intervention to curtail 'scroungers and skivers' and 'benefit tourism', as promulgated by the UK parties, especially the UK Conservative and United Kingdom Independence Party, but also including the Labour Party (Unwin, 2012; The Guardian, 2013). Framing public policy in Scotland, around social justice is not new, but was rather a continuation of established political discourse (O'Hagan, 2015). However, there is an enduring disconnect between public opinion and political framing. Curtice (2013:6) signals that "public opinion in Scotland has not been immune from the wider trend evident across the UK as a whole towards a less sympathetic view towards at least some 
aspects of welfare" revealing an enduring gap between the reality of attitudes to benefits payments and the perceptions of a higher level of commitment to social justice.

\section{Framing and advocating gender equality}

Early in the referendum campaign, Kenny (2014) raised concerns about the apparent absence of women's voices and presence. This visibly changed over the course of the campaign as women became more prominent in the political parties. Nicola Sturgeon, then Deputy Leader of the SNP, led her party's independence campaign. Ruth Davidson as leader of the Scottish Conservatives; and to a lesser degree, Johan Lamont in the leadership role for Scottish Labour were key figures for Better Together. Women for Independence (WfI) developed a strong grassroots base through local campaigning and meetings across Scotland and its founders became regular contributors to popular and political media and events. Women activists were less visible in the 'No' campaign with little evidence of comparable activity.

Other women's and feminist organisations also ran events with women across Scotland. Principal among these were Engender and the Scottish Women's Convention (SWC). Engender is a membership organisation that describes itself as "Scotland's feminist organisation", pursuing gender equality and women's emancipation from a broadly liberal feminist perspective, with an overlay of feminist economics analysis. SWC is not an explicitly feminist organisation and is funded by the Scottish Government as an intermediary organisation to facilitate consultation and dialogue with women. The analyses of women's views collated by these organisations reflect a wide range of issues of concern to women across the policy domains of social security and taxation; economy and employment, skills and training; education; health; representation in political and corporate spheres; international leverage for advancing women's economic, social and political status, and women's engagement in developing Scotland's constitutional future. Synthesising these concerns, Engender proposed a vision for Scotland where

"women and men have equal opportunities in life, equal access to resources and power, and are equally safe and secure from harm. We wish to live and work in a country in which women and men are represented as equals in the media and in public life and have an equal voice in shaping and making political decisions - where gendered discrimination has been consigned to history.” (Engender, 2014a: 3)

\section{What would a 'women-friendly welfare state' in Scotland look like?}

In this highly charged and energised moment in time how was the future of social security being conceived? To what extent were the characteristics of Hernes' (1987) concept of a 'womenfriendly welfare state' and its revisiting by Borchorst and Siim (2002) in evidence? 
A women-friendly society "would not force harder choices on women than on men" and "injustice on the basis of gender would be largely eliminated without an increase in other forms of equality, such as among groups of women" (Hernes, 1987:15). This 'grand vision' of women's social rights and political inclusion (Borchorst and Siim, 2002:92) was claimed to be realisable through a combination of women's organising and mobilising from the bottom up and appropriate institutionalisation of gender through political, legislative and governance structures. Arguably, that vision for women in the Nordic countries as "empowered as political subjects through the institutionalisation of gender equality" is evident in Scotland.

In addition to women's organising and mobilising at grassroots and community level, there are a number of formal equality bodies and institutional structures charged with the advancement of equality and human rights in Scotland. The Equality and Human Rights Commission, the Equal Opportunities Committee of the Scottish Parliament, the Equality Unit of the Scottish Government, and the Equality Budget Statement are examples of institutions or processes that, at least on the surface, seek to advance gender equality as a political goal in the context of promoting gender equality based on a series of equality laws and political commitment. However, the evidence from the independence debate and subsequently suggests that the opportunity for re-defining the 'welfare state' in Scotland as focus of transformative change for women as workers, citizens and mothers has not been maximised by formal institutions.

Borchorst and Siim (2002: 91) contend there is an "analytical distinction between womenfriendly social policies and polices that contribute to enhance[ing] gender equality". It should be possible, they argue, to "distinguish between different dimensions of welfare and strategies that stress equality, strategies that stress diversity and difference; and the civil, social, and political dimensions of citizenship". Nyberg (2002:74) signalled a significant caveat that welfare policy can be used to advance gender equality, but the "welfare state also has the potential to reproduce the power relationships that exist between women and men". Borchorst and Siim (2002: 91-92) echo this concern as they argue that there is a "crucial difference" between "women-friendliness and gender equality friendliness". The former seeks to respond to women's experience of disadvantage through policies around childcare and work life balance that can reinforce gendered norms, rather than the more transformative potential of policies that seek to rebalance and recast gender relations.

How then did the policies and proposals on social security from political parties and civil society voices in the referendum debate, and the subsequent proposals on further powers for the Scottish Parliament following the no vote conform with or run counter to the characterisation by Borchorst and Siim? 
To answer this, using the keywords 'women', 'gender', and 'equality' the substantive policy and campaign documents from political parties comprising Yes Scotland and Better Together were scrutinised. Table 1 contains the results from the political parties.

Table 1 Political parties, women and gender

\begin{tabular}{|l|c|c|c|}
\hline Source and name of publication & Women & Gender & Equality \\
\hline $\begin{array}{l}\text { Scottish Conservative and Unionist Party (2014) } \\
\text { Commission on the Future Governance of Scotland. }\end{array}$ & 0 & 0 & 0 \\
\hline $\begin{array}{l}\text { Scottish Government (Scottish National Party) (2014a) } \\
\text { Scotland's Future: Your Guide to an Independent } \\
\text { Scotland }\end{array}$ & 39 & 18 & 125 \\
\hline $\begin{array}{l}\text { Scottish Green Party (2014) Jobs-rich, fair and } \\
\text { flourishing: An Economy for All }\end{array}$ & 7 & 0 & 3 \\
\hline \begin{tabular}{l} 
Scottish Labour (2014a) Together We Can. \\
\hline $\begin{array}{l}\text { Scottish Labour (2014b) Powers for a purpose - } \\
\text { Strengthening Accountability and Empowering People. } \\
\text { Scottish Labour Devolution Commission. }\end{array}$
\end{tabular}$\quad 10$ & 4 & 24 \\
\hline $\begin{array}{l}\text { Scottish Liberal Democrats (2012) Federalism: The best } \\
\text { future for Scotland. }\end{array}$ & 0 & 0 & 0 \\
\hline
\end{tabular}

A more detailed reading of these documents reveals that the SNP and Green Party exhibited some gender awareness as their policy proposals fall somewhere between women-friendly and gender equality friendly. For example, the Green Party takes a social investment approach that most closely reflects the feminist framing of proposals for 'social security' rather than 'welfare'. They consider childcare expansion a policy priority, principally in the interest of the child and as a secondary measure for 'making work accessible for all'. Ultimately childcare is framed as a gender equality measure, but stemming from the underlying analysis that women are currently the primary care providers.

Across the other parties a form of Adult Worker Model underlies formal approaches to social security reconfiguration, with a focus on driving all adults towards the labour market. For example, in Powers for a Purpose the Scottish Labour party discusses 'welfare' principally as pensions and cash benefits and the "collection of social services that help people in their everyday lives" (Scottish Labour Party, 2014a: 173). 'Welfare' was considered a constituent part of the social union whereby risks and resources are pooled across the UK. Scottish Labour analysis offers no 
context of the care economy, differential experiences of social security, nor the relevance of employment and care provision to shaping the future of social security policy. Instead the focus is primarily on limited proposals for devolution of administrative processes of particular cash benefits. The Scottish Conservatives offered no proposals on women, social security or equality in their Future Governance of Scotland report on devolution. Only the proposals from the SNP and Scottish Green Party are explicit on these points.

Table 2 characterises proposals in the key policy documents from the main political parties and civil society organisations engaged in the debate on the future of social security in Scotland by how they reflect a gender analysis or a 'women-friendly' approach, if at all.

Table 2 Gender equality character of main policy proposals

\begin{tabular}{|c|c|c|c|}
\hline & Women friendly social policy & Enhancing gender equality & $\begin{array}{l}\text { No gender analysis } \\
\text { (gender blind) }\end{array}$ \\
\hline Scottish Labour & No proposals & $\begin{array}{l}\text { Limited to women on corporate } \\
\text { and public boards }\end{array}$ & $\begin{array}{l}\text { Administrative devolution of } \\
\text { certain benefits/transfers }\end{array}$ \\
\hline $\begin{array}{l}\text { Scottish } \\
\text { Conservatives }\end{array}$ & No proposals & No proposals & $\begin{array}{l}\text { Administrative devolution of } \\
\text { certain benefits/transfers }\end{array}$ \\
\hline $\begin{array}{l}\text { Scottish National } \\
\text { Party }\end{array}$ & Transformational childcare & $\begin{array}{l}\text { Childcare } \\
\text { Addressing occupational } \\
\text { segregation }\end{array}$ & \\
\hline $\begin{array}{l}\text { Scottish Green } \\
\text { Party }\end{array}$ & $\begin{array}{l}\text { Childcare } \\
\text { Citizen's Basic Income }\end{array}$ & $\begin{array}{l}\text { Making work accessible for all } \\
\text { through childcare } \\
\text { Making work pay through } \\
\text { Living Wage and not } \\
\text { subsidised wages by tax credits }\end{array}$ & \\
\hline $\begin{array}{l}\text { Scottish Liberal } \\
\text { Democrats }\end{array}$ & No proposals & No proposals & \\
\hline Common Weal & In place of anxiety & & \\
\hline $\begin{array}{l}\text { Expert Group on } \\
\text { Welfare }\end{array}$ & & Citizen's Basic Income & \\
\hline Engender & & $\begin{array}{l}\text { Investment in care economy; } \\
\text { decoupling childcare from } \\
\text { women-friendly social policy; } \\
\text { tackling domestic abuse and } \\
\text { gender-based violence. } \\
\text { Integration of intersectional } \\
\text { gender analysis in policy } \\
\text { analysis. }\end{array}$ & \\
\hline
\end{tabular}




\begin{tabular}{|l|l|l|l|}
\hline & Women friendly social policy & Enhancing gender equality & $\begin{array}{l}\text { No gender analysis } \\
\text { (gender blind) }\end{array}$ \\
\hline $\begin{array}{l}\text { Scottish Women's } \\
\text { Budget Group }\end{array}$ & $\begin{array}{l}\text { Investment in social } \\
\text { infrastructure and care } \\
\text { economy. Gender analysis of } \\
\text { public policy proposals and } \\
\text { budget process; individual } \\
\text { rather than household } \\
\text { entitlements to social security } \\
\text { benefits; ensure devolved } \\
\text { taxation regime based on } \\
\text { principles of gender justice; }\end{array}$ & \\
\hline $\begin{array}{l}\text { Smith } \\
\text { Commission }\end{array}$ & $\begin{array}{l}\text { Administrative devolution of } \\
\text { elements of Universal Credit } \\
\text { could be responsive to } \\
\text { gendered analysis and calls for } \\
\text { payments not to be monthly } \\
\text { and only to one member of the } \\
\text { household. }\end{array}$ & $\begin{array}{l}\text { No gender analysis despite } \\
\text { gendered dimensions to } \\
\text { proposals for devolving benefits } \\
\text { such as Carer's Allowance, } \\
\text { elements of } \\
\text { workfare/employability } \\
\text { programmes, elements of } \\
\text { Universal Credit }\end{array}$ \\
\hline
\end{tabular}

The concern emerging from the evidence is not the absence of women's advocacy for gender equality, but rather that it appears to have been contained within feminist or women's organisations. Despite the presence and voices of women clearly articulating specific demands and proposals, there was a failure in emerging policy venues and established political structures and institutions to reflect these demands or present a gendered analysis of their own proposals.

In Scottish Independence: A Feminist Response Cat Boyd and Jennifer Morrison (2014) present a radical socialist feminist critique of the Radical Independence Campaign propositions as a clearly articulated radical response to the absence of gender analysis and of the invisibility of women in presence and policy in political organisations.

Common Weal was established in 2012 within the left-wing policy think tank, the Jimmy Reid Foundation. Its purpose was to generate debate and progressive policy proposals in social and economic policy for an independent Scotland, under its campaign slogan "All of us first". "In place of anxiety" (McKay and Sullivan, 2014) was the main publication commissioned by Common Weal specifically on future social security provision. It integrated the feminist economics perspective and analysis of the late Ailsa McKay (Campbell and Gillespie, 2016). However, women's economic and social status was not central to Common Weal's analytical concerns or discursive frames for the formulation of policy interventions or diagnostic starting points.

By August 2014 Common Weal had produced 38 commissioned publications on taxation, economy, local and national democratic representation and participation, poverty and inclusion. These publications contained 85 references to women, 15 to gender and 145 to equality (including inequality). Common Weal published its only explicitly feminist and gendered analysis think piece, Women o' independent mind (Author, 2014b) as a brief incursion into the maleness of the debate. Produced as a consensual piece of edited views and priorities from consultation with socialist 
feminist activists, Women o' independent mind proposed maximising the opportunity of independence for feminist transformative change that could secure greater economic, social and political independence for women.

On the evidence so far it seems that gender equality was not a guiding principal either of the main political parties or of non-feminist contributions to the referendum debate. Women-friendly social policy was limited to some childcare concessions and the emphasis from Labour and the SNP of women on corporate and public boards. Although presented as concessions to gender equality arguably they have little transformative weight, characterisable as attempts at descriptive representation by redressing some of the imbalance in corporate decision making.

The evidence suggests that neither women nor gender equality were central factors in the deliberative processes of the main parties and campaigning groups in the referendum. Furthermore, there was little conceptual engagement around women and social security or the extent to which policies were directed at women (women-friendly) or had a more transformative intent, aiming to advance gender equality. These tensions are most obvious in the attempts to expand the debate on childcare and wider questions of social care infrastructure. These issues are discussed as a feminist critical frame analysis in the following section, drawing from conceptual propositions of the discursive politics of gender equality policy offered by Lombardo, Meier and Verloo (2009).

\section{Shifting the balance of care}

Affordable, accessible, flexible childcare is a long-standing feminist demand for women's emancipation and for recasting gender relations. The SNP trumpeted an approach to 'transformational childcare' in Scotland's Future: Your Guide to an independent Scotland, the White Paper on Scottish independence. The transformative intent had previously been advanced by feminist advocates Campbell, McKay and Elson (2013) who had proposed decoupling childcare from its traditional conceptualising as a women-friendly social policy and instead framing it as a combined economic and social policy that would advance gender equality. They argued that public investment in childcare is beneficial to the economy as both capital and social investment in economic and social infrastructure through expanding the childcare estate, workforce and increasing labour market access for parents, particularly women. Campbell et al., and subsequently the Scottish Government, argued that in an independent Scotland, revenue from the expanded tax base of all workers, including additional childcare workers, would be retained in Scotland and could be channelled into further investment in social infrastructure.

Childcare has been consistently presented as being inherently of interest to women, based on a gendered frame that locates women in traditional roles of primary carer. As feminist advocates of 'transformational childcare', Campbell et al., (2013) stretched the transformative potential of 
investing in childcare as investment in social and economic infrastructure across a number of feminist arguments in relation to the balance of care and undervaluing of the provision of care. Specifically they sought to highlight the significant deficiencies of established models of the formal economy that maintain the invisibility of unpaid care and undervaluing of paid care, mainly undertaken by women, but which remain disregarded in systems of national accounting and economic policy. Further evidence of stretching and bending gender equality frames (Lombardo et al. 2009) is evident in the alignment with dominant government frames of boosting economic growth and easing pressure on public spending on social security through increased labour market participation. There are risks however to bending gender equality aims into a frame that presents women's equality as being realised or even contingent upon their labour market participation, based on concerns that policy makers may simply seek to add women on to frameworks where the male norm prevails, such as the labour market (Sainsbury, 1999).

The arguments for investing in childcare framed gender equality as integral to economic development and economic policy but were bent differently by feminist advocates and the political parties pursuing women's votes. The proposition on childcare was presented in the Scottish Government's White Paper with little additional contextual analysis. Arguably, this resulted in a discursive collision between the political frame of advancing women's equality through a version of an Adult Worker Model and the feminist frame of an emancipatory policy supporting women's economic independence in part through increased labour market access. The focus of the feminist argument on increasing the social and monetary value of the provision of care was diluted in the White Paper and became instrumentalised as the key means to women's labour market participation from which greater equality of economic status would flow. This met with criticisms from some feminist sources and a challenge to policymakers to look beyond childcare on the basis that it is not a proxy or panoply for feminist policy change (Engender, 2014a).

Elsewhere, the Expert Group on Welfare and Constitutional Reform (Scottish Government, 2014b) considered the future of welfare in an independent Scotland. It exhibited a determined effort to integrate gender analysis in the wider debate on social care and its proposals on Carer's Allowance, Social Security Allowance and a form of Citizen's Basic Income acknowledged the impact of unpaid care on women. With a perspective informed by feminist analysis, the Expert Group articulated a desire for a more equitable, person-centred approach to social security that combines a safety net throughout the lifecycle, and transitions based on a social investment system that regards social security as investing in the wellbeing and potential of all citizens.

\section{A fluid state: proposals post Referendum}


An immediate response of the UK government to the 'no' vote was to announce a special commission to lead a process of further devolution for Scotland in the context of greater parity across the UK. The Smith Commission announced on 20 September 2014 comprised representatives from each of the main political parties in Scotland. Three of the ten members were women.

The Commission received 407 written submissions from civic institutions, organisations and groups, and 18,381 from members of the public. Lord Smith and the Commission secretariat attended 25 events across Scotland with over 215 organisations and groups participating, including one all-women event. ${ }^{1}$ The Smith Commission recommendations are part of an unfolding story in UK and Scottish politics as further powers were proposed in the 2015 Scotland Bill. ${ }^{2}$

\section{Women's voices in Smith and beyond}

The proposals for further devolution in the Scotland Bill 2015 extending from the Smith process present a patchwork of administrative autonomy, confused liability for spending decisions as evidenced in long-running negotiations for the Fiscal Framework (HM Government and Scottish Government, 2016)), and, most significantly for individuals, the potential of confusion and difficulties in accessing income and resources (The Poverty Alliance, 2015). Proposals for further devolution of social security are limited in scope as they comprise Disability Living Allowance, Attendance Allowance, Winter Fuel Payments, Carer's Allowance, Industrial Injuries Disablement Benefit, Severe Disablement Allowance, Discretionary Housing Payments, Personal Independence Payments, Funeral Payments, Sure Start Maternity Grants, and Cold Weather Payments but not employment-related benefits. These account for $£ 2.547 \mathrm{bn}$ or $14 \%$ of the total spend on social security payments in Scotland (Scottish Parliament, 2015b).

Have women's voices and feminist gender equality policies gained any further institutional purchase since the referendum? Engender (2014b), SWBG (SWBG, 2014), Scottish Council for Voluntary Organisations (SCVO, 2014), and WfI, among others, all contributed to the consultation phase of the Smith Commission and subsequently. Key issues again included social security, taxation, equalities legislation and the imperative that all further powers should be subject to robust equality impact assessment with the advancement of gender equality as their starting point. However, feminist organisations have expressed their disappointment with the Commission recommendations and Scotland Bill provisions including through the Joint Ministerial Working Group (Engender 2014c), the Scottish Parliament Welfare Reform Committee Inquiry and in public

\footnotetext{
${ }^{1}$ The Smith Commission Report, 27 November 2014. Available at: https://www.smithcommission.scot/smith-commission-report/

${ }^{2}$ Scotland Bill 2015-16. Available at: http://services.parliament.uk/bills/2015-16/scotland.html
} 
statements during the course of the Scotland Bill (Engender, 2015a). Of note is the influence of Engender in the decision of the Scottish Parliament's Welfare Reform Committee to initiate and report on its Inquiry into Women and Welfare (Scottish Parliament, 2015d). In coalition with feminist and non-feminist organisations, Engender crafted the evidence base and preferred feminist policy responses in Scotland into 'A Widening Gap: Women and Welfare Reform' (Engender, 2015b).

In addition to raising awareness of the implications for women of reconfiguration of benefits and transfers proposed under devolution powers and the impact of UK government measures, a key outcome from the Committee Inquiry has been a re-framing of its focus from welfare to social security. Following evidence from researchers from WiSE at Glasgow Caledonian University, including Visiting Professor Diane Elson to the Committee in May 2015 in which they pressed the Committee to change its conceptual approach to welfare and consider reframing to social security and protection, the Committee changed the name of the Inquiry report (Scottish Parliament, 2015c).

The Committee Inquiry was also a further opportunity to promote Plan F: A Feminist Economic Strategy produced by the UK and Scottish Women's Budget Groups as a campaigning platform in advance of the 2015 UK General Election. Plan F is a series of demands for a caring and sustainable economy, based on feminist analysis of economic and social policy and presented as a direct challenge to the perceived failure of the 'Plan A' of UK Chancellor George Osborne to redress the imbalance between public spending, public debt, and structural deficit.

Figure 1 Plan F for a caring and sustainable economy

- $\quad$ Reverse cuts to public services and social security spending that have particularly adverse effects on women, such as the 'bedroom tax' and household benefit cap.

- $\quad$ Reform Universal Credit to provide an adequate independent income for all over the life course, by ensuring that women with employed partners gain from earning and that not all the money goes to one person in a household.

- Borrow to invest in social infrastructure - public services providing care, health, education and training - as well as physical infrastructure, such as renewable energy and environmentally friendly public transport

- Strengthen workers' rights throughout the economy, including the terms and conditions of work of the paid workforce, both directly employed and subcontracted, who staff the social infrastructure, and raise the national minimum wage to a level that ensures a decent living.

- $\quad$ Ensure access to high quality affordable care through care that is both publicly funded and publicly provided

- Improve support for people - currently mainly women - who provide unpaid care in families and communities. We need a social security system that promotes fairer sharing of care and its costs.

- $\quad$ Increase investment in social housing and insulating homes

- $\quad$ Paying for Plan F by:

- $\quad$ cancelling any replacement for Trident

- $\quad$ reversing tax reductions introduced since 2010: reductions in duties on fuel and alcohol; rises in the Personal Income Tax threshold; introduce transferable tax allowances and corporation tax cuts

- $\quad$ taking effective action on tax debt, avoidance and evasion 
The italicized text in Figure 1 above highlights the areas where there is scope for the Scottish Government to take action or have acted to protect women's financial and economic independence and to treat women as individuals, workers and carers within a more gender-neutral social security regime in Scotland.

\section{Future familialisation?}

In 2015, the UK government made clear its determination to continue to cut 'welfare' spending by a further $£ 12$ bn from 2015-2017(UK Government, 2015). In addition to its focus on reducing public spending, Conservative policies on taxation and benefits reflect what Daly (2011) has described as a "neo-familialist" approach whereby women are granted some rights as carers such as a level of subsidised childcare.

As for the welfare state as "an active site of adjudication of claims" (Annesely 2007), proposals for the immediate future of social security in Scotland continue to be a mix of Male Breadwinner and Adult Worker Models. Rather than framing potentially transformative gender-friendly policy as a recasting of gender relations, the SNP continued to pursue social policy constructed around the family. The "Family Manifesto" for the 2015 General Election campaign (SNP, 2015) was a basket of policies committed to expand childcare and free school meals, increase child tax credits, update some benefits, increase the minimum wage, improve maternity discrimination protection, protect free prescriptions and maintain "fee-free" higher education. The anti-austerity measures intended to "stand up for Scotland's families and lock austerity out of Westminster policies" included increased spending through Westminster budgets to stop cuts in public services (while maintaining the Council Tax freeze in Scotland), stop Trident renewal and increase UK government investment in affordable housing. This potent mix of social and economic policy cuts across the demands of Plan $F$ but it also muddies the lines between devolved and reserved competence across policy domains and therefore has significant implications for the wellbeing of families in Scotland. Moreover, there is still no clear distinction between women-friendly social policy and gender equality-friendly policy. This political appeal to the "benefits for families of voting SNP" (SNP, 2015) reinforces the underlying construct of families and households as the dominant frame at UK and Scottish government levels. It accentuates Daly's warning (2011:6) that this approach to welfare provision as a combination of labour market activation and social cohesion through the 
family construct foregrounds the family and "casts gender in the shade as reforms are constructed in gender neutral terms that endorse familiazation.

The combination of measures in the UK government's welfare reform programme have delivered cuts in transfers such as child benefit and Sure Start maternity grants that support women's income. In particular, the introduction of Universal Credit has been severely criticised by feminist scholars and activists (Bennett and Sung, 2013; UKWBG various; Engender, 2015) as signifying a return to a Male Breadwinner Model by rolling together a number of cash transfers into a monthly payment to a single, named household claimant, most likely the principal (male) earner. The introduction of Universal Credit, it has been argued, will disincentivise (female) second earners and remove even more independent control of household finances and possibility of escape for women in abusive relationships (UKWBG, 2013). This destabilising of women's income along with tax giveaways that benefit men has had a cumulative effect not only on women's incomes but on their financial independence and economic status (UK Women's Budget Group, 2015).

According to Daly (2011:11) "full-time motherhood is no longer idealised by policy" as evidenced in the changes to benefits for lone parents, requiring women parents of children of oneyear and over to engage in 'mandatory work activity'. So women as workers are treated as economic agents but also penalised for performing parenthood and primary caring roles. The individual with family bonds and familial embeddedness is the ideal social policy subject" (Daly 2011:16) a construct privileged in the dominant political discourse from government and opposition parties in the UK parliament. As evident in the focus on an 'economy that works for working people' and improving conditions for 'hard working families' ${ }^{3}$ refrains favoured by the Conservative and Labour Parties invoking "hard-working" and "hard pressed" families in the construction of economic policy having to "work for working people" as reinforced by the trade unions (CLASS, 2015) and expressed in the SNP's "Manifesto for Families".

This treatment of women as proxy Adult Workers, being driven increasingly towards the labour market and away from state support through the social security system, has been applied without the recasting of gender relations necessary to decouple women from the principal caring roles within the family. Therefore a form of Adult Worker Model is being constructed that purports to treat women and men the same without considering "the complexities of the issues inherent in care work" (Lewis, 2002:336). Sustained investment in the social infrastructure that would bridge the

\footnotetext{
3 The Guardian, 20 March 2015, David Marsh "Welcome to the election. But only if you're a hardworking family". At http://www.theguardian.com/media/mind-your-language/2015/mar/20/welcome-to-the-election-but-only-if-youre-ahardworking-family; "Cameron's betrayal of hard-working families”, Labour Party at http://www2.labour.org.uk/hardworking-families;
} 
gap between demand and supply of care services has not kept pace with the policy proposals from the main political parties who have promised extensions in hours of publicly provided childcare, for example, without the necessary infrastructure investment (McLean, 2015).

\section{Conclusion}

Are feminist voices making a difference within the wider policy community in Scotland? What strength and force do feminist voices have within political parties and policy making venues? Have the calls for gender analysis across public policy domains since the independence referendum been accepted and activated within non-feminist policy venues?

This article has evidenced a disconnect between policy discourses within the formal political spaces of political parties and the arguments advanced by feminist voices. The elements of the gender regime (Pascall and Lewis, 2004) of paid work, care, income, time and voice are not aligned to the dominant policy discourse of either the UK government or, to a lesser extent, the Scottish Government in relation to social security reform. None of the tensions between women's emancipation and economic independence through waged labour and support from the "welfare state' as proposed by Nyberg (2002) were in evidence from the non-feminist organisations, reinforcing Nyberg's concerns that the 'welfare state', and thereby treatment of social security policy without a feminist analysis, has the power to liberate women but also to reproduce power relationships.

The evidence discussed here suggests a reality in Scotland where women outside government, prominent in a small and interconnected polity have the capacity and power to engage politically, but their core demands and perspectives are not integrated into mainstream policy making. There is clearly effective organised political agency and capacity within feminist civil society organisations to secure access to the political process and present robust analyses of the impact on women of welfare reform and public sector spending. Despite this however, formal institutional politics even within self-styled radical organisations, still has no 'grand vision' for gender equality.

The evidence from across campaigning and political organisations presented here has demonstrated the enduring failure to locate gender equality as a central policy focus. While opportunities for change and integration of gendered analysis continue to exist as the devolution process continues, the rather disappointing reality seems to affirm the pessimistic view that women have limited "political clout" to shape the "welfare state' despite their "substantial status as political, social and economic citizens" within it (Annesley 2007: 461).

It is clear that an overarching gender analysis is still missing from the mainstream visions of future social security regime in Scotland. Policy is being developed within a version of an Adult 
Worker Model frame, cloaked in vestiges of the Male Breadwinner Model and single-earner households that no longer reflects social reality.

Women's political empowerment may be more visible and vibrant in Scotland since the independence debate, but despite the political opportunities of ongoing constitutional and political change, women's voice and presence are still not resulting in the institutional engagement and commitment to gender analysis necessary to advance gender equality policy. This will remain the case so long as the parties retain their preference for re-worked 'women-friendly' rather than gender equal social policy.

\section{References}

Annesley, C (2007) Gender, Citizenship and Participation: Women's Political Agency and Welfare Reform: Engendering the Adult Worker Model. Parliamentary Affairs 60 (3): 452-466.

Black, A (2015) BBC Scotland News Fiscal framework: What is Scotland's new funding deal? 22 November, 2015Available at: http://www.bbc.co.uk/news/uk-scotland-scotland-politics-34889958. (accessed 21 December 2015).

Banaszak, L A, Beckwith, K and Rucht, D (eds.) (2003) Women's movements facing the reconfigured state. Cambridge: Cambridge University Press.

Beckwith, K (2007) Mapping Strategic Engagements: women's movements and the state. International Feminist Journal of Politics, 9(3): 312-338.

Bennett, F and Sung, S (2013) Dimensions of financial autonomy in low-/moderate-income couples from a gender perspective and implications for welfare reform. Journal of Social Policy, 42(04): 701-719.

Borchorst, A and Siim, B (2002) "The women-friendly welfare states revisited", NORA - Nordic Journal of Feminist and Gender Research, 10 (2): 90-98.

Boyd, C and Morrison, J (2014) Scottish Independence: A feminist response. Edinburgh: Word Power. (ISBN: 9780992739249).

Campbell, J and Gillespie, M (2016) Feminist Economics and Public Policy: Reflections on the Work and Impact of Ailsa McKay, eds. Jim Campbell and Morag Gillespie. London: Routledge (forthcoming 2016).

Campbell, J, Elson, D and McKay, A (2013). The Economic Case for Investing in High-Quality Childcare and Early Years Education. WiSE Briefing Sheet, November. Glasgow: Glasgow Caledonian University. Available at: www.gcu.ac.uk/media/WiSEBriefingPaperNov13.pdf. (accessed 20 May 2015).

Chappell, L (2010) Comparative gender and institutions: Directions for research. Perspectives on Politics, 8(1): 183-189.

Charles, N and Mackay, F (2013) "Feminist politics and framing contests: Domestic violence policy in Scotland and Wales" Critical Social Policy, 2013, 33(4): 593-615. 
Curtice, J (2013) "Is it really all just about economics? Issues of nationhood and welfare?" Scottish Social Attitudes Survey. Available at: http://www.natcen.ac.uk/media/265694/ssa_is-it-really-alljust-about-economics.pdf (accessed 24 January 2015).

Daly, M (2011) What Adult Worker Model? A Critical Look at Recent Social Policy Reform in Europe from a Gender and Family Perspective. Social Politics Volume 18(1):1-23.

Engender (2012) Multiple Jeopardy? The impacts of the UK Government's proposed welfare reforms on women in Scotland. Edinburgh: Engender.

Engender (2014a) Gender Equality and Scotland's Constitutional Futures. Edinburgh: Engender.

Engender (2014b) Engender submission to the Smith Commission on devolution. Edinburgh. Available at: http://www.engender.org.uk/content/publications/Engender-Smith-Commissionsubmission-October-2014.pdf (accessed 20 January 2015).

Engender (2015a) Women, further devolution and social security: A statement to the Joint Ministerial Working Group on Welfare. Available at:

http://www.engender.org.uk/content/publications/A-statement-to-the-joint-ministerial-working group-on-welfare.pdf. (accessed 27 August 2015).

Engender (2015b) A Widening Gap: Women And Welfare Reform. Edinburgh: Engender. Available at: http://www.engender.org.uk/content/publications/A-Widening-Gap---Women-andWelfare-Reform.pdf (accessed 20 August 2015).

The Fawcett Society (2013) The Impact of Austerity on Women, Fawcett Society, March 2013. Available at: http://www.fawcettsociety.org.uk/2013/03/the-triple-jeopardy-2-2/ (accessed 3 May 2015).

Graham, H and McQuaid, R (2014) Exploring the impacts of the UK government's welfare reforms on lone parents moving into work. Glasgow Centre for Population Health.

http://www.gcph.co.uk/publications/497_impacts_of_welfare_reforms_on_lone_parents_moving_in to_work_report (accessed 30 May 2015).

Grice, A (2014) The Independent 6 December 2014. Available at: http://www.independent.co.uk/news/uk/politics/women-bear-85-of-burden-after-coalition's-taxand-benefit-tweaks (accessed 28 May 2015).

Hernes, H M (1987) Welfare state and women power. Essays in state feminism. Oslo: Norwegian University Press.

Hetherington P (2011) The Guardian 6 September 2011. Available at: http://www.theguardian.com/society/2011/sep/06/scotland-john-swinney-spending-cuts (accessed 28 May 2015).

HM Government and Scottish Government (2016) The agreement between the Scottish Government and the United Kingdom Government on the Scottish Government's fiscal framework. Available at: https://www.gov.uk/government/uploads/system/uploads/attachment_data/file/503481/fiscal_frame work_agreement_25_feb_16_2.pdf. (accessed 12 March 2016).

Institute for Fiscal Studies (2015) "Green Budget". Available at: http://www.ifs.org.uk/publications/7530 (accessed 4 September 2015) 
Keating, M. and Wilson, A. (2009) Renegotiating the State of Autonomies: Statute Reform and Multi-level Politics in Spain. West European Politics, 32 (3): 536 - 558.

Kenny, M (2014) Engendering the Independence debate. Scottish Affairs 23(3): 323-331.

Lewis, J (2002) Gender and welfare state change. European Societies, 4(4): 331-357.

Lombardo, E, Meier, P and Verloo, M (eds.). (2009) The discursive politics of gender equality: Stretching, bending and policy-making. Abingdon: Routledge.

McKay, A and Sullivan, W (2014) In Place of Anxiety: Social Security for the Common Weal. Glasgow: Common Weal. Available at:

http://www.allofusfirst.org/tasks/render/file/?fileID=DF06657B-0516-476C-B6CF455893DC3F7F (accessed 20 April 2015).

McLean, C (2015) “Queen's speech 2015: the experts respond” Available at: https://theconversation.com/queens-speech-2015-the-experts-respond-42427 (accessed 6 June 2015).

Mackay, F (2010) Gendering constitutional change and policy outcomes: substantive representation and domestic violence policy in Scotland. Policy \& Politics, 38(3), 369-388.

Mishra, R (1990) The Welfare State in Capitalist Society: Politics of Retrenchment and Maintenance in Europe, North America and Australia. University of Toronto Press.

Mooney, G, Scott, G, and Williams, C (2006) "Introduction: Rethinking social policy through devolution". Critical Social Policy 26 (3): 483-497.

Nyberg, A (2002) "Gender, (de)commodification, economic (in)dependence and autonomous households: the case of Sweden". Critical Social Policy 22(1): 72-95.

O’Hagan, A (2016) with Morag Gillespie "Gender budgeting in Scotland: Seeking transformative change through public spending" in Feminist Economics and Public Policy: Reflections on the Work and Impact of Ailsa McKay, eds. Jim Campbell and Morag Gillespie. London: Routledge.

O'Hagan, A (2015) "Implementing Gender Budgeting in Scotland and Spain: A Comparative Feminist Analysis" in Discursive Governance in Politics, Policy, and the Public Sphere, eds. Umut Korkut, Kesi Mahendran, Gregg Bucken-Knapp, Robert Henry Cox. New York: Palgrave Macmillan.

O'Hagan, A (2014a) Women o' independent mind: Gender equality in an independent Scotland., Common Weal. Available at: http://www.allofusfirst.org/library/women-of-an independent-mind-the-future-of-womens-equality-in-scotland-2014/.

O'Hagan, A (2014b) The Yes and No sides both want women's votes - but they have a funny way of showing it, The Conversation, online: 25 August, http://theconversation.com/the-yes-and-no sides-both-want-womens-votes-but-they-have-a-funny-way-of-showing-it-30840.

Ormiston, R (2014) “Minding the gap. Women's views of independence in 2014”. Edinburgh: ScotCen. 
Pascall, G and Lewis, J (2004) Emerging gender regimes and policies for gender equality in a wider Europe. Journal of Social Policy, 33(3): 373-394.

Phipps, C (2013) The Guardian 27 February 2013. Available at:

http://www.theguardian.com/society/blog/2013/feb/27/scroungers-and-skivers-language-yourstories. (accessed, 21 December 2015).

The Poverty Alliance (2015) Welfare Trackers Research Briefing No. 2

Universal Credit: Issues for Glasgow. Available at:

http://povertyalliance.org/userfiles/files/WelfareBriefingNo2_UniversalCredit.pdf. (accessed 21

December 2015).

Rummery, K. (2015) “Devolving social policy: is Scotland a beacon for fairness?" In Defence of Welfare 2. Social Policy Association at: http://www.social-policy.org.uk/wordpress/wpcontent/uploads/2015/04/Rummery.pdf.

Sainsbury, D (1999) Gender and welfare regimes. Oxford University Press.

Scottish Conservative and Unionist Party (2014) Commission on the Future Governance of Scotland.

Scottish Government (2013) Equality Statement Scottish Draft Budget 2014-15. Available at:http: //www.gov.scot/Publications/2013/09/9971/downloads. (accessed 10 March 2015).

Scottish Government (2014a) Scotland's Future: Your Guide to and Independent Scotland. Available at: http://www.scotland.gov.uk/Publications/2013/11/9348. (accessed 24 May 2015).

Scottish Government (2014b) Re-Thinking Welfare: Fair, Personal and Simple. Second report of the Expert Working Group on Welfare. Edinburgh: Scottish Government. Available at: http://www.gov.scot/Resource/0045/00451915.pdf.

Scottish Government (2015a) Scotland's Spending Plans and Draft Budget 2016-2017. Edinburgh: Scottish Government. Available at: http://www.gov.scot/Resource/0049/00491140.pdf. (accessed 21 December 2015).

Scottish Government (2015b) Scotland's Economic Strategy. Edinburgh: Scottish Government.

Scottish Government (2015c) Fiscal Framework debate. Available at:

http://news.scotland.gov.uk/News/Fiscal-Framework-debate-1e0a.aspx. (accessed 21 December 2015).

Scottish Green Party (2014) Jobs-rich, fair and flourishing: An Economy for All. Available at: http://www.scottishgreens.org.uk/wp-content/uploads/downloads/2014/04/Green-Yes-Jobsbriefing.pdf. (accessed 12 March 2015).

Scottish Labour (2104a) Together we can. Available at:

http://www.scottishlabour.org.uk/campaigns/entry/together-we-can. (accessed 20 June 2014).

Scottish Labour Party (2014b) Powers for a Purpose- Strengthening Accountability and Empowering People. Report from Scottish Labour Devolution Commission. Available at: 
.http://www.scottishlabour.org.uk/page/Scottish\%20Labour\%20Devolution\%20Commission\%20re port.pdf. (accessed 20 June 2014).

Scottish Liberal Democrats (2012) Federalism: The best future for Scotland. Available at: http://www.scotlibdems.org.uk/homerule. (accessed 24 March 2015).

Scottish National Party (2015) Families Manifesto.

Scottish Parliament Welfare Reform Committee (2015a), Women and Welfare Inquiry: Summary of Evidence WR/4/15/9/3, 19 May 2015. Available at:

http://www.scottish.parliament.uk/S4_Welfare_Reform_Committee/Meeting\%20Papers/Papers_20 150519.pdf. (accessed 10 June 2015).

Scottish Parliament (2015b) Devolution (Further Powers) Committee New Powers for Scotland: An Interim Report on the Smith Commission and the UK Government's Proposals. [Online]Available at: http://www.scottish.parliament.uk/S4_ScotlandBillCommittee/Reports/dfpr-15-03w-rev.pdf. (accessed 27 August 2015).

Scottish Parliament (2015c) Welfare Reform Committee, Official Report 19 May 2015. Available at: http://www.scottish.parliament.uk/parliamentarybusiness/report.aspx?r=9967\&mode=pdf. (accessed 21 December 2015).

Scottish Parliament (2015d Welfare Reform Committee Women and Social Security SP Paper 773 3rd Report, 2015 (Session 4) Published 6th July 2015. Available at: http://www.scottish.parliament.uk/S4_Welfare_Reform_Committee/Reports/wrr-15-03w.pdf (accessed 21 December, 2015)

Scottish Parliament (2015d) Finance Committee Scotland's Fiscal Framework, 12th Report, 2015 (Session 4). Available at: http://www.scottish.parliament.uk/S4 FinanceCommittee/Reports/fir1512w.pdf. (accessed 21 December 2015).

Scottish Women's Budget Group (2014) Statement to Smith Commission. Available at: http://www.swbg.org.uk/content/publications/SWBG-Statement-to-Smith-Commission.pdf (accessed 28 May 2015).

United Kingdom Government (2015), Queen's Speech. Available at: https://www.gov.uk/government/topical-events/queens-speech-2015 (accessed 27 August 2015).

Unwin, J (2012) "Welfare reform debate ignores the facts about poverty", Joseph Rowntree Foundation. Available at: https://www.jrf.org.uk/blog/welfare-reform-debate-ignores-facts-aboutpoverty (accessed 21 December 2015).

Vickers, J (2013) "Is Federalism Gendered? Incorporating Gender into Studies of Federalism". Publius: The Journal of Federalism 43(1):1-23.

Women's Budget Group (UK) (2015) The impact on women of the Autumn Statement and Comprehensive Spending Review 2015: Still failing to invest in women's security. Available at: http://wbg.org.uk/wpcontent/uploads/2015/04/WBG_AFS_CSR_2015_report_2015_12_07_final3. pdf. (accessed 2 March 2016) 
Women's Budget Group (UK) (2014) Response to the Autumn Financial Statement 2014. Available at: http://wbg.org.uk/wp-content/uploads/2015/01/WBG-AFS-final.pdf (accessed 20 May2015).

Women's Budget Group (UK) (2012) WBG Response to Work and Pensions Committee Third Report of Session 2012 - 13, 'Universal Credit Implementation: meeting the needs of vulnerable claimants'. Available at: http://wbg.org.uk/economic-social-policy/universal-credit/ (accessed 28 May 2015).

Dr Angela O'Hagan is a Lecturer in Social and Public Policy at Glasgow Caledonian University. Her doctoral dissertation was a comparative analysis of gender budgeting in Scotland and autonomous communities in Spain. Previously she had an established career in policy analysis and advocacy across equalities and social justice in Scotland within third and statutory sectors. Her main research interests are comparative gender equality analysis in public policy, gender budgeting, and equality and human rights analysis. Recent publications include: O'Hagan, A. (2015) 'Favourable Conditions for the Adoption and Implementation of Gender Budgeting: Insights from Comparative Analysis', Politica Economica-Journal of Economic Policy 31(2); O'Hagan, A., Addabbo, T. and Gunluk-Senesen, G. (2014) 'Perspectives on gender equality' in McKendrick, J.H. et al (eds) Poverty in Scotland, Child Poverty Action Group. Address: Department of Social Sciences, Media and Journalism, Glasgow Caledonian University, 70 Cowcaddens Road, Glasgow G4 0BA, Scotland. email: angela.ohagan@gcu.ac.uk 